УДК 94(47)"1941/45"

UDC

DOI $10.17223 / 18572685 / 40 / 6$

\title{
БЕССАРАБИЯ В ГОДЫ ВЕЛИКОЙ ОТЕЧЕСТВЕННОЙ ВОЙНЫ
}

С.Г. Суляк

Национальный исследовательский

Томский государственный университет

Россия, 634050, г. Томск, пр. Ленина, 36

E-mail: sergei_suleak@rambler.ru

Scopus Author ID: 55359315000

Researcher ID: D-6981-2014

http://orcid.org/0000-0001-5040-9080

SPIN-код: 6908-8277

\section{Авторское резюме}

28 июня 1940 г. Бессарабия была присоединена к СССР. 2 августа из большинства ее уездов и районов Молдавской Автономной Советской Социалистической Республики была образована Молдавская Советская Социалистическая Республика. 22 июня 1941 г., с началом Великой Отечественной войны, на территории республики начались военные действия. Несмотря на ожесточенные бои, в которых принимали участие и уроженцы Бессарабии, к концу июля 1941 г. край был оккупирован немецко-румынскими войсками. В результате мобилизации в Красную армию и эвакуации население Молдавии сократилось на 500 тыс. чел. и составило 2 млн 220 тыс. чел. Население Кишинёва, Тирасполя и уездных центров сократилось почти вдвое. Оккупанты создали губернаторство Бессарабия. Многочисленные приказы органов «новой власти» с различными ограничениями, запретами, запрещениями, как правило, заканчивались словами: «за нарушение - смертная казнь», «тюремное заключение сроком на...», «каторжными работами от... до...». Румынские власти проводили политику террора и грабежа. Планировалось переселить местное русское, гагаузское, болгарское, русинское и малорусское население, а их земли заселить румынскими колонистами. В Румынию вывозились продовольствие, фураж, промышленные товары, дефицитное сырье. Были разрушены экономика края, системы образования и здравоохранения. Все это пришлось восстанавливать после освобождения Молдавии в августе 1944 г.

Ключевые слова: Бессарабия, Молдавия, МССР, Великая Отечественная война, Вторая мировая война, Румыния, СССР. 


\title{
Bessarabia During the Years of the Great Patriotic War
}

\author{
S.G. Sulyak \\ National Research Tomsk State University \\ 36 Lenin Avenue, Tomsk, 634050, Russia \\ E-mail: sergei_suleak@rambler.ru
}

\section{Abstract}

On June 28 Bessarabia entered into the structure of the USSR. On August 2, 1940 the Moldavian Soviet Socialist Republic was formed from the majority of districts of Bessarabia and the Moldavian Autonomous Soviet Socialist Republic. With the beginning of the Great Patriotic War on June 22, 1941 military operations began on the territory of the republic. Despite the fierce battles, in which the Bessarabians took part, by the end of July 1941 Bessarabia was occupied by the German-Rumanian forces. As a result of mobilization into the Red Army and evacuation, the Moldavian population decreased by 500000 and was at 2220000 . The population of Kishinev, Tiraspol and district centers decreased approximately by half. An administrative region of Bessarabia was created by the occupying forces. The numerous commands of the "new authorities" with various restrictions, bans, prohibitions as a rule ended with: "Death penalty for violation of", "prison sentence for a term of...," "hard labor from... to.... The occupying forces conducted a policy of terror and plunder. The resettling of local Russian, Gagauz, Bulgarian, Rusin and the Little Russian population was planned and the lands of the former were colonized by Rumanian colonists. Provisions, fodder, manufactured goods, raw material of short supply were exported to Rumania. The economy, education and health systems were destroyed. In August 1944 after the liberation of Bessarabia everything had to be restored.

Keywords: Bessarabia, Moldavia, MSSR, Great Patriotic War, WWII, Rumania, USSR.

Бессарабия была отторгнута от России в 1918 г. бывшим ее союзником - королевством Румыния. Советская Россия, а затем СССР не признавали законность аннексии и настаивали на возвращении этой территории в состав России / СССР. 28 июня 1940 г. бессарабский вопрос был мирно решен. Бессарабия и Северная Буковина вошли в состав СССР. 2 августа 1940 г. был принят Закон об образовании союзной Молдавской Советской Социалистической Республики (МССР). В состав МССР вошли г. Кишинев, Бельцкий, Бендерский, Кагульский, Кишиневский, Оргеевский и Сорокский уезды Бессарабии, г.Тирасполь, Григориопольский,Дубоссарский, Каменский, Рыбницкий, Слободзейский и Тираспольский районы МАССР. Остальные районы 
автономной республики, а также Аккерманский, значительная часть Измаильского и Хотинского уездов (где преобладало украинское, т.е. русинское и малоросское население. - С.С.). Бессарабии отошли к Украинской ССР. Северная Буковина и часть Хотинского уезда вошли в состав Черновицкой области УССР.

Численность населения МССР на 1 января 1941 г. составила 2 млн 719,3 тыс. чел. (Кустрябова 1986: 33).

В созданной республике начались формирование новых органов управления, восстановление промышленности и сельского хозяйства, принимались меры по улучшению благосостояния населения. 10 февраля 1941 г. была принята Конституция МССР.

Однако мирному строительству помешала война.

22 июня 1941 г. фашистская Германия вероломно напала на СССР. Союзником Германии выступила Румыния ${ }^{1}$. На советско-румынской границе были сосредоточены три армии (11-я немецкая, 3-я и 4-я румынские) общей численностью свыше 600 тыс. чел. Им противостояли войска Одесского военного округа (переименованного в первый день войны в 9-ю армию) и отдельные части 18-й армии (История 1968: 421-422; Репида 2008: 173). 18-я армия была дислоцирована на Буковине. Большая часть уроженцев Молдавии была призвана в состав 9-й армии, особенно много бессарабцев было в частях 35-го и 48-го стрелковых корпусов (Молдавская ССР 1975: 9). Кишинев прикрывала 95-я стрелковая дивизия² 35-го стрелкового корпуса (называвшаяся с 16.01.1934 г. Молдавской), состоявшая в основном из уроженцев Бессарабии (Шорников 2014: 90).

На юго-западном направлении был создан Южный фронт ${ }^{3}$ в составе 9-й и 18-й армий, 2, 16 и 18-го механизированных корпусов (Тюленев 1972: 129). Бои развернулись на всей территории республики. Первый удар врага приняли пограничники. Местные жители помогали рыть окопы. Нередко жители соседних молдавских сел непризывного возраста (многие - участники Первой мировой войны) сражались с оружием в руках вместе с пограничниками (Молдавская ССР 1975: 126-127). Снабжали жители окрестных сел бойцов и продовольствием (Репида 2008: 174).

С первых дней войны в городах и районах Молдавии было создано 63 истребительных батальона численностью до 100-200 чел. в каждом. Десятки тысяч бессарабцев работали в фортификационных батальонах (Молдавская ССР 1975: 150-154). К 5 июля 1941 г. в ряды РККА в ряды вступило 47,6 тыс. призывников (Репида 2008: 176). В рядах Красной армии воевало 38 тыс. солдат-бессарабцев, дезертировавших из румынской армии в июне 1940 г., 18 тыс. рабочих и служащих (Шорников 2007: 268). 
Почти на всем протяжении границы враг был отброшен на исходные позиции. Красная армия и пограничники не только отражали атаки противника, но и переходили в контрнаступление. 25-26 июня подразделения 51-й стрелковой дивизии и 79-го морпогранотряда на бронекатерах Дунайской флотилии переправились через Килийское гирло и овладели городом Килия-Веке и рядом населенных пунктов Румынии (История 1968: 422-423; Шорников 2014: 90). Это единственный случай в начале войны, когда было выполнено положение советской военной доктрины: «Бить врага на его территории и малой кровью» 4 .

Из донесения командующего Южным фронтом И.В. Сталину, С.К.Тимошенко и Г.К. Жукову об итогах двухнедельных боёв фронта от 8 июля 1941 г.: «В результате двухнедельных боев армии Южного фронта продолжают удерживать рубеж р. Прут и р. Дунай, за исключением участка Снятын, Штакешты, где правофланговые части 18-й армии отходят на новый оборонительный рубеж в связи с отходом левого крыла ЮЗФ» (ЦАМО 1: 10).

Несмотря на то что десятки тысяч людей ушли на фронт, промышленные и торговые предприятия, почта, телеграф продолжали бесперебойную работу. На 120-140 \% выполняли свои дневные нормы рабочие кишиневских моторемонтного, чугунолитейного и механического заводов и других предприятий. Ушедших в армию заменили подростки, женщины, девушки, старики (История 1968: 427; Молдавская ССР 1975: 41-46, 681-696).

4 июля 1941 г. СНК МССР и ЦК КП(б) Молдавии приняли постановление о порядке эвакуации населения и промышленных предприятий (Шорников 2014: 100). В восточные районы СССР были эвакуированы основные предприятия, весь общественный скот колхозов, продовольственные запасы, ценное оборудование и материалы, а также педагогические вузы, селхозинституты, опытные научные сельскохозяйственные учреждения, работники науки и культуры. По данным конца 1942 г., было эвакуировано до 300 тыс. чел. По неполным данным, на конец 1942 г. в 16 областях и республиках ССР было учтено до 100 тыс. чел. Остальное население, видимо, было вынуждено остаться на оккупированной врагом территории Украины (Молдавская ССР 1975: 274-275).

В результате мобилизации в Красную армию и эвакуации население Молдавии сократилось на 500 тыс. чел. и составило 2 млн 220 тыс. чел. Население Кишинёва, Тирасполя и уездных центров сократилось почти вдвое (на 230 тыс. чел.) (Шорников 1994: 25).

Эвакуировалось большинство горожан: 65 \% жителей Кишинева, 67 \% жителей Бельц, 58 \% жителей Тирасполя, 53 \% жителей Бендер, 
45 \% жителей Оргеева. Среди них много было евреев, которые понимали, что принесет им «новый порядок»: 90 \% евреев - жителей Тирасполя, Бендер, Калараша, около 80 \% евреев Кишинева, Бельц, Скулян и т. д. Всего было эвакуировано или ушло в Красную армию свыше 60 \% евреев Бессарабии (более 170 тыс. чел.) (Шорников 2014: 103-104).

На восток отправили 4076 вагонов с промышленным оборудованием, сельскохозяйственными машинами, зерном, продовольствием и около 180 тыс. голов скота (История 1968: 430; Молдавская СССР 1975: 276).

Уроженцы Молдавии работали в тылу на фабриках и заводах Москвы, Саратова и Урала, в шахтах Караганды и Кузбасса, на нефтепромыслах Азербайджана и Туркмении, на железнодорожном транспорте, в колхозах и совхозах Казахстана, республик Средней Азии, Кавказа, внося свой вклад в победу над врагом (Молдавская ССР 1975: 11, 282-285, 287, 290, 296, 297, 301-304, 307-309, 316-318).

В тылу были восстановлены учебные заведения, учреждения науки и культуры. Эвакуированное население за счет добровольных взносов собрало к концу 1942 г. свыше 200 тыс. руб. на танковую колонну «За Советскую Молдавию» (Молдавская ССР 1975: 275), 600 тыс. руб. (до начала марта 1943 г.) - на эскадрилью «За освобождение Молдавии от немецко-румынских захватчиков». К 8 марта 1943 г. 100 тыс. руб. на строительство самолета им. Героя Советского Союза Марии Расковой собрала группа женщин из Молдавии. Собирались деньги на строительство катеров «Морской охотник», активно велась подписка на военный заем (История 1968: 456-457; Молдавская ССР 1975: 277-282).

Бои на территории Молдавии продолжались почти полтора месяца - до конца июля. Однако из-за прорыва немецко-фашистских войск на левом фланге Юго-Западного фронта советские войска вынуждены были с боями отступить.

5 июля части 3-й румынской армии вошли в г. Черновцы, а к 9 июля полностью заняли Северную Буковину. Северный фланг 9-й армии, оборонявшей Бессарабию, оказался под угрозой.

16 июля 1941 г. был занят Кишинев. 26 июля Красная армия была вынуждена полностью оставить территорию Бессарабии (История 1968: 433; Тарас 2004: 37-38).

Для подпольной работы в тылу врага партийными органами республики был утвержден состав 13 партийных организаций и 8 партизанских отрядов в левобережных районах Молдавии и 139 партизанских отрядов в правобережных (История 1968: 429). К марту 1944 г. в Молдавии насчитывалось 28 подпольных организаций и групп, объединявших более 500 чел., 8 партизанских отрядов и 23 
группы численностью 900 чел. (История 2002: 237-238). Несмотря на тяжелые условия борьбы (открытая местность, небольшое количество лесов, скопления вражеских войск в городах и селах), действовавшие партизанские отряды летом 1944 г. пустили под откос 14 вражеских эшелонов, взорвали 9 мостов, уничтожили 25 танков и бронемашин, около 400 автомашин и 700 повозок с боеприпасами и снаряжением (Молдавская ССР 1976: 24).

Маршал Советского Союза Н.И. Крылов, в то время бывший начальником штаба Дунайского укрепрайона, вспоминал: «То, что войска, действовавшие тут, смогли удержать границу в первый день войны и долго удерживали потом, имело, мне кажется, значение не только для того времени и не только для данного участка фронта. Без стойкой обороны у Дуная и Прута, а затем на Днестре вряд ли удалось бы остановить врага под Одессой» (Крылов 1984: 17; Репида 2008: 177).

За время оборонительной операции в Молдавии (1.07. - 26.07.1941 ट., по Г.В. Кривошееву. - С.С.) потери Южного фронта (имевшего 364700 чел. полного состава) составили: безвозвратные - 8519 (2,3%), санитарные - 9374 чел. (Россия и СССР 2001: 310).

Румынская армия в ходе боев в Бессарабии потеряла убитыми 31638 солдат и офицеров (Шорников 2014: 108). К сожалению, данные о потерях немецкой армии на этом направлении не известны. Всего же в боях между Прутом и Бугом румынская армия потеряла 130 тыс. чел. убитыми, ранеными, пропавшими без вести. Немецкий историк А. Хильгрубер на основании данных, предоставленных немецкому командованию, считает, что румынская армия с начала войны до 6 октября 1941 г. потеряла 70 тыс. убитыми и 100 тыс. ранеными (Левит 1981: 181).

К Румынии были присоединены захваченные Бессарабия и Северная Буковина. Одновременно Гитлер предложил И. Антонеску занять зону между Днестром и Днепром для «обеспечения ее безопасности» взамен участия в военных действиях к востоку от Днепра. Территория между Днестром и Бугом была названа Транснистрией. По декрету об образовании Транснистрии ее северная граница проходила по линии Хотин - Могилев-Подольский - Ямполь - Рудника - р. Савранка (История Румынии 1971: 344).

Для руководства и координации действий оккупационной администрации при кабинете министров был создан специальный орган - Военно-гражданский кабинет для администрации Бессарабии, Буковины и Транснистрии (КББТ) (Левит 1981: 238).

Как вели себя румынские «освободители» ${ }^{5}$ на территории созданных ими губернаторств, видно по приведенным ниже фактам.

Для управления захваченной территорией были созданы три губернаторства: Бессарабия (центр - г. Кишинёв), Буковина (г. Черновцы) 
и Транснистрия (с 19 августа до 17 октября 1941 г. - г. Тирасполь, а затем - г. Одесса). В Бессарабии было размещено 9 жандармских легионов. Число жандармов и полицейских в октябре 1941 г. составило 4282 чел. (Шорников 2007: 270).

На все руководящие посты назначались выходцы из Румынии. Они возглавляли префектуры (уездные администрации), претуры (волостные (plasa) администрации), примэрии (городские управы). В городах действовали военно-полевые суды. Помимо армии, карательные функции выполняли жандармерия, полиция, сугуранца (тайная полиция), органы Специальной службы информации (Serviciul special de informație (SSI)) - секретной полиции, подчинявшейся непосредственно И.Антонеску (Молдавская ССР 1976: 7).

Многочисленные приказы органов «новой власти» с различными ограничениями, запретами, запрещениями, как правило, заканчивались словами: «за нарушение - смертная казнь», «тюремное заключение сроком на...», «каторжными работами от... до...» (Молдавская CСР 1976: 7, 36, 61-64, 96-97, 130-134).

В губернаторстве Бессарабия, по данным властей, на 1 января 1942 г.числилось 799 (из 1162 уцелевших) действующих предприятий с числом рабочих на каждом свыше 10 чел. или двигателем свыше 5 л.с., спустя год - 992, а на 15 июля 1943 г. - 1 037, в том числе 777 мельниц и 165 маслобоек. 492 предприятия было объявлено «военизированными», на Буковине - 192. Рабочие, прикрепленные к этим предприятиям, обязаны были трудиться сколько нужно и по твердым расценкам, без права оставлять работу по собственномужеланию. Почти вся продукция этих заводов и фабрик отправлялась в Румынию или использовалась на месте для снабжения войск и оккупационной администрации (Левит 1981: 295-296).

В Румынию вывозились продовольствие, промышленные товары, дефицитное сырье, например кожевенное. В то же время потребности городского населения, как отмечается в отчете губернаторства Бессарабия, были удовлетворены в 1942 г. на 7 \%, а в 1943 г. - на 4,37 \%. Обувь распределялась только среди чиновников оккупационного аппарата (Левит 1981: 296-297).

По данным КББТ, из губернаторств Бессарабия и Транснистрия до начала августа 1943 г. в Румынию вывезли 93 тыс. вагонов зерновых, 8 тыс. вагонов продовольствия, 6,4 тыс. вагонов фуража и овощей, 96,1 тыс. голов скота, 171 тыс. штук кож животных, 72,2 тыс. птиц, 8,4 тыс. вагонов других ценностей. Также немало продовольствия и фуража было изъято для румынской, немецкой, венгерской и итальянской армий (Царанов 2002: 96).

Оккупанты решили оставить колхозы и совхозы. В марте 1942 г. колхозы были превращены в «трудовые общины», земли делились 
между бригадами из 20-30 родственных семей. Бригады, связанные круговой порукой, обязаны были обработать от 200 га земли и большую часть урожая сдать государству (Молдавская ССР 1976:11, 104).

На месте совхозов были созданы так называемые государственные хозяйства (История 1968: 439).

В губернаторствах Бессарабия и Буковина после уборки урожая каждый крестьянин обязан был подписывать так называемую декларацию (заявление) с данными о наличии у семьи зерновых и других сельхозпродуктов. Специальные сельскохозяйственные агенты в сопровождении жандармов врывались в дома крестьян для проверки наличия зерновых. На пропитание оставляли по 80 кг зерна на взрослого и 40 кг - на ребенка, остальное подлежало сдаче оккупационным властям по ценам ниже рыночных. За несвоевременную подачу декларации, предоставление ложных сведений, утаивание сельскохозяйственных продуктов полагалось наказание вплоть до заключения в лагерь (Левит 1981: 300).

В результате только в Бессарабии посевная площадь сократилась на 13 \% (Левит 1981: 307).

Также все жители губернаторства обязаны были ежегодно отрабатывать 30 дней на строительстве дорог военного значения (фактически срок был больше) (Молдавская ССР 1976:110-111, 121-122). Уклонение от выполнения дорожной, как и всякой другой повинности каралось тюремным заключением. К примеру, каждый крестьянин сел Бужоровка и Застынка Сорокского района с января по август 1942 г., выполняя всякие трудовые повинности, отработал в среднем от 40 до 120 дней. Это же было характерно и для Транснистрии (Молдавская ССР 1976: 122; Левит 1981: 314).

Оккупанты полностью разрушили систему образования. В директивах, составленных М. Антонеску для оккупационной администрации, указывалось: «В Бессарабии и на Буковине школа должна быть перестроена коренным образом. Пока не должно быть открыто в этих провинциях ни одного высшего учебного заведения... В начальной школе мужчины будут обучаться земледелию, а женщины - хозяйству». В губернаторстве Бессарабия с населением в 2,4 млн чел. (по данным на конец 1941 г.) было всего 10 общеобразовательных полных средних и 11 неполных средних школ, 3 педагогических училища и 1 духовное училище, в которых занималось в 1941/1942 учебном году около 9 тыс. учащихся.

Доступ в них ввиду высокой платы за обучение имели в основном дети чиновников оккупационной администрации. Низкой была посещаемость в школах, особенно начальных. Основная причина этого, как выясняется из отчетов школьного ведомства, - отсутствие у детей одежды и обуви. В губернаторстве Буковина посещаемость 
составляла 60,8 \%. Жандармские органы объясняли это и тем, что местное население «не желает обучать их на румынском языке». В 1942/1943 учебном году, например, в губернаторстве Бессарабия не обучалоись 139550 детей в возрасте от 7 до 16 лет. Еще в худшем положении находились школы в губернаторстве Транснистрия (Левит 1981: 283-284).

В 1941-1942 гг. в губернаторствах Бессарабия и Буковина была устроена проверка «благонадежности» учителей и учеников. Многие педагоги лишились права преподавания, учащиеся были исключены из учебных заведений (Молдавская ССР 1976: 9, 99-100, 108, 126; Левит 1981: 285).

На всей территории от Прута до Буга сохранилось лишь одно высшее учебное заведение - Одесский университет, на шести факультетах которого обучалось всего 1756 студентов. При университете оккупационные власти создали Институт антикоммунистической пропаганды (Левит 1981: 286).

Была развалена система здравоохранения. В трех уездах Молдавской ССР (Кишиневском, Кагульском, Бендерском) осталось 38 врачей. Это означало, что один врач приходился примерно на 20 тыс. жителей. Среди населения распространялись эпидемии. Так, в губернаторствах Бессарабия и Буковина осенью 1941 г. случилась вспышка сыпного тифа (Левит 1981: 320).

Согласно секретному предписанию кишиневского областного инспектората от 14 августа 1941 г. , у бессарабцев были изъяты все советские и румынские удостоверения личности. Вместо них выдавались удостоверения трёх цветов: для румын (молдаван) - белого цвета, для национальных меньшинств - жёлтого, для евреев - зелёного. Также были введены специальные цифры, указывавшие на политическую принадлежность (цифра «3» - для подозрительных, «5» - для коммунистов, «7» - для легионеров) (Молдавская ССР 1976: 51-53).

Приказом губернаторства Бессарабия от 15 ноября 1941 г. было запрещено разговаривать в публичных местах на «чужом» языке. Нарушение приказа каралось тюремным заключением сроком от одного месяца до двух лет. Одновременно с тюремным заключением суд мог приговорить «виновного» к крупному денежному штрафу и лишить права занимать государственную должность сроком на шесть лет (Молдавская ССР 1976: 82). Население продолжало игнорировать распоряжения румынской администрации. Военно-полевые суды были завалены делами «преступников» (Суляк 2010: 11-13).

Румынские оккупанты вынашивали планы насильственного выселения русского, украинского (малоросского и русинского. - С.С.), болгарского, гагаузского, еврейского, цыганского населения (Молдавская 
ССР 1976: 8). 8 июля 1941 г. руководитель румынского государства (кондукэтор) И. Антонеску заявил на заседании румынского правительства, что он выступает «за насильственную миграцию всего еврейского элемента Бессарабии и Буковины, его нужно выставить за переделы наших границ. Также я за насильственную миграцию украинского элемента, которому здесь нечего делать в данный момент» (Молдавская ССР 1976: 35). Согласно распоряжению маршала (с 21 августа 1941 г.) И. Антонеску, в декабре 1941 г. было принято юга Бессарабии, «откуда гагаузы должны быть перемещены путем применения различных экономических мер с целью переброски их на Украину» (Молдавская ССР 1976: 96). В октябре 1942 г. в соответствии с приказом Антонеску рассматривался «план эвакуации болгарского населения с юга Бессарабии» (Молдавская ССР 1976: 127). 20 июля 1943 г. губернатор Бессарабии дивизионный генерал О. Ставрат довел до подведомственных органов, что «имеются села национальных меньшинств (русские, украинские, гагаузские), которые не включаются в ритм сегодняшнего дня, а некоторые жители этих сел не подчиняются сразу полученным приказам и особенно при выполнении трудовой повинности, господин маршал, глава государства, разрешил отправлять этих инородцев за Днестр, а их недвижимое имущество секвестировать в пользу государства» (Молдавская ССР 1976:152).

Румынские оккупационные органы собирались в результате выселения из Бессарабии «чуженационального» населения, главным образом из Белгород-Днестровского, Новокилийского, Измаильского, Кагульского, Бендерского, Бельцкого уездов (всего 702,1 тыс. чел., в том числе украинцев (русинов и малороссов. - С.С.) - 250,7 тыс., русских - 158,1 тыс., болгар - 117,6 тыс., гагаузов - 115,7 тыс. чел.), получить не менее 300 тыс. га дополнительных земель. Движимое и недвижимое имущество нацменьшинств в сельской местности оценивалось в 24,1 млрд леев, в городах - в 2,6 млрд леев (Левит 1981: 272-273).

С начала оккупации создаются гетто в Кишиневе, с июля 1941 г. лагеря, «в которых следовало собрать всех евреев» (Молдавская ССР 1976: 88-95), выселяются в Транснистрию и цыгане (Молдавская ССР 1976:153).

В лагерях Транснистрии в годы румынской оккупации погибло более 300 тыс. евреев и 50 тыс. цыган. А всего, с учётом уничтоженных летом и осенью 1941 г. на территории Бессарабии и Буковины, число евреев - жертв геноцида составляло не менее 350 тыс. чел. (Назария 2005: 275).

С апреля 1943 г. из Рыбницкого района румынские власти по приказу И. Антонеску начинают эвакуировать местное украинское 
население (с конца апреля до начала июля их было выселено 3 тыс. чел.), на их место «должны быть поселены румыны с Кавказа», а также с Кубани и Крыма (Молдавская ССР 1976: 149-150).

Подобные меры предполагалось принять и на Буковине. В письме от 12 декабря 1942 г. на имя И. Антонеску (который 24 июля 1941 г., прибыв в Черновцы, объявил, что будет «лично руководить организацией Бессарабии и Буковины» (Левит 1981: 236)), глава ведомства румынизации и колонизации Румынии писал: «С точки зрения национальных интересов необходимо в первую очередь удалить украинское и рутенское (m. е. русинское. - С.С.) население» как самое «многочисленное». За счет этой «эвакуации» румынские власти рассчитывали приобрести в области 216 тыс. га пахотных земель и 98,6 тыс. га земель других угодий, а всего (т.е. после выселения также русских, поляков, гуцулов) 247,7 и 128,7 тыс. га соответственно (Левит 1981: 272).

В 1942/1943 финансовом году румынизированное имущество принесло казне по губернаторству Бессарабия чистой прибыли более 1 млрд леев, по Буковине - 500 млн леев (Левит 1981: 274).

Оккупационные власти пытались принять насильственные меры по румынизации фамилий и имен. Однако из-за противодействия местного населения эта политика провалилась (Молдавская ССР 1976: 114-115; Левит 1981: 281-282).

«Сделать Бессарабию самой крепкой в румынской вере», как отмечал в июне 1942 г. в своей докладной записке Министерству пропаганды Румынии заместитель директора управления пропаганды губернаторства Бессарабия Д. Мыцулеску, было сложно (Левит 1981: 280), «так как бессарабский крестьянин всегда считал себя молдаванином, а не румыном и смотрел на выходцев из Старого королевства с некоторым пренебрежением, что является следствием того, что он находился в составе великой империи» (Молдавская ССР 1976: 113-114).

Большую проблему для оккупантов создало использование мобилизационного ресурса Бессарабии. К началу войны в румынской армии служили 7,8 тыс. бессарабцев, призванных до вхождения этой территории в состав СССР. Румынское командование использовало этот «ненадежный» контингент в тыловых и оккупационных частях. К концу 1941 г. румынская администрация взяла на учет 84,8 тыс. бессарабцев от 17 до 21 лет, используя их как рабочую силу. После Сталинградской битвы 8,8 тыс. чел. из них было мобилизовано. Накануне освобождения Бессарабии оккупанты попытались эвакуировать всех допризывников и мужчин призывного возраста, а также мобилизовать их в армию. Речь шла о 250 тыс. чел. (Шорников 2014: 
332-333). В отчете от 1 июня 1944 г. губернатор Бессарабии дивизионный генерал О. Ставрат сообщал о том, как ответило население Бессарабии на призыв «о защите родины»: «Сами явились от 2 до 10 \%; были пойманы и отправлены жандармами в воинские части 36-38 \%; из допризывников сами явились и были переправлены за Прут от 20 до 30 \%; были собраны и отправлены жандармами от 40 до 50 \%; на реквизиции сами явились 40-45 \%; силой реквизировано жандармами 30-35 \%. Дезертиры, скрывшиеся призывники и не явившиеся на реквизиции, преследуются жандармами» (Молдавская ССР 1976: 192-193).

Случаи массового дезертирства из румынской армии были постоянными (Молдавская ССР 1976: 294), как и массовая сдача в плен Красной армии (Шорников 2014: 337). В сентябре 1943 г.более 5 тыс. уроженцев Бессарабии, Буковины и Одесской области, чтобы избежать службы в румынской армии и не воевать против своих, вступило в ряды Русского корпуса на Балканах (Русский корпус 1963: 17, 115; Дробязко 2004: 93).

После освобождения Молдавии с марта по ноябрь 1944 г.в Красную армию ушло более 240 тыс. чел. (Молдавская ССР 1975: 9).

Ушли на фронт и два родных брата моего отца, Иван и Ефим, скрывавшиеся в годы оккупации от призыва в румынскую армию.

Суляк Иван Георгиевич (1920-1945), уроженец с. Булгак Рышканского района Молдавской ССР, был призван 8 ноября 1944 г. РВК Рышканского района Бельцкого уезда МССР.Последнее место службы - 1331-й стрелковый Краснознаменный полк 318-й горнострелковой Новороссийской дивизии 6 . Красноармеец И.Г. Суляк погиб в боях за Родину 15 апреля 1945 г. в ходе Моравско-Остравской наступательной операции. Похоронен в Польше (Катовицкое воеводство ${ }^{7}$, Рыбникский повят, г. Лослау южнее, 10 км, центр п. Шахта Фридриха, дивизионное кладбище, братская могила № 24, 2-й ряд, 6-й с юга).Там же, в списках павших, числится и его двоюродный брат и односельчанин Суляк Андрей Яковлевич, 1918 г.р. (братская могила № 23, 3-й ряд снизу) (ЦАМО 2: 2-4). Однако позже оказалось, что сведения о гибели Андрея оказались ошибочными (ЦАМО 3:451). В 20-страничном Донесении о безвозвратных потерях от 30 апреля 1945 г. № 57856 и 24-страничном Донесении об оказавшихся в живых (документе, уточняющем потери) встречаются русинские и молдавские фамилии уроженцев Буковины и Бессарабии (ЦАМО 2; ЦАМО 3).

Суляк Ефим Георгиевич (1920-1995), тоже уроженец с. Булгак, был призван Михалянским военкоматом Бельцкой области, «беспартийный, на фронте борьбы с японскими захватчиками с 9.8.45 г.». Воевал в 58-м стрелковом полку 190-й стрелковой дивизии Первого Даль- 
невосточного фронта. 28 августа 1945 г. был награжден медалью «За боевые заслуги». Как записано в Приказе № 7/н от 25 августа 1945 г. по 58-му стрелковому полку: «...награждаю медалью “За боевые заслуги”... снайпера 8 ср (стрелковой роты. - С.С.) красноармейца Суляка Ефима Георгиевича за то, что огнем из ручного пулемета уничтожил двух японских солдат и был ранен, превозмогая боль, пошел вместе с ротой в атаку» (ЦАМО 4: 4).

Война нанесла огромный ущерб экономике МССР. Помимо вывезенных ценностей, оккупанты разрушили 1037 промышленных предприятий. Сумма причиненного ущерба составила 2 млрд руб. (Царанов 2002: 99). Были уничтожены 63849 чел., подвергнуто истязанию и пыткам 20345 чел., угнано на работы 47242 чел. Большой урон понес жилому фонду. У колхозов было разрушено 4800 строений, у государственных предприятий и учреждений - 16499 строений (в том числе 8434 дома). Ряд населенных пунктов (Унгены, Корнешты, местечко Валя-луй-Влад Кишкаренского района) был полностью разрушен. В Кишиневе осталось 24 \% жилого фонда. (Молдавская ССР 1976: 230-231). Было разрушено 607 школ (Молдавская ССР 1976: 207). Всего ущерб составил 16 млрд руб. (в 34 раза больше бюджета республики в 1941 г.) (Царанов 2002: 101).

Восстановление народного хозяйства республики началось сразу после ее освобождения (таблица). Благодаря самоотверженному труду населения, помощи союзного правительства и союзных республик, в Молдавии к 1948 г.в основном были восстановлены промышленность и сельское хозяйство (несмотря на засуху и неурожай 1945-1946 гг. и голод 1946-1947 гг., последствия которых удалось преодолеть благодаря помощи из союзного бюджета) (Царанов 2002: 117, 141).

Некоторые данные по экономике Молдавии (1940-1945 гг.)

\begin{tabular}{|l|c|c|c|c|}
\hline \multicolumn{1}{|c|}{ Показатель } & 1940 г. & 1941 г. & 1944 г. & 1945 г. \\
\hline $\begin{array}{l}\text { Производство электроэнергии, милли- } \\
\text { он киловатт-часов }\end{array}$ & 172 & 11,2 & 0,8 & 8,3 \\
\hline Производство кожаной обуви, тыс. пар & 159 & 80 & 13 & 73 \\
\hline Производство сахара-песка, тонн & 11600 & 3290 & 351 & 1854 \\
\hline $\begin{array}{l}\text { Производство мяса (без производства } \\
\text { колхозами, считая субпродукты } \\
\text { І категории), тонн }\end{array}$ & 5623 & 3931 & 955 & 5614 \\
\hline Производство животного масла, тонн & 140 & 155 & 159 & 184 \\
\hline $\begin{array}{l}\text { Производство растительного масла, } \\
\text { тонн }\end{array}$ & 13988 & 12359 & 5921 & 11774 \\
\hline
\end{tabular}


GGGР в Велнкой ОтЕчественной войне 1941-1945 гГ.: взГАЯА нз ХХІ века

\begin{tabular}{|l|c|c|c|c|}
\hline $\begin{array}{l}\text { Производство консервов, } \\
\text { тысяч условных банок }\end{array}$ & 48475 & 11398 & 3 & 534 \\
\hline $\begin{array}{l}\text { Валовой сбор зерновых } \\
\text { культур по всем категориям } \\
\text { хозяйств, тысяч тонн }\end{array}$ & 1810 & - & 1037 & 962 \\
\hline $\begin{array}{l}\text { Валовой сбор сахарной свеклы по } \\
\text { всем категориям хозяйств, тысяч тонн }\end{array}$ & 119 & - & 55 & 68 \\
\hline $\begin{array}{l}\text { Валовой сбор подсолнечника по всем } \\
\text { категориям хозяйств, тысяч тонн }\end{array}$ & 162 & - & 70 & 100 \\
\hline $\begin{array}{l}\text { Валовой сбор картофеля по всем } \\
\text { категориям хозяйств, тысяч тонн }\end{array}$ & 147 & - & 78 & 146 \\
\hline $\begin{array}{l}\text { Площади зерновых культур во всех } \\
\text { категориях хозяйств, тысяч гектаров }\end{array}$ & 1672 & - & 1271 & 1565 \\
\hline $\begin{array}{l}\text { Производство мяса по всем катего- } \\
\text { риям хозяйств, в убойном весе, тысяч } \\
\text { тонн }\end{array}$ & 51 & 3 & 34 & 31 \\
\hline $\begin{array}{l}\text { Производство яиц по всем категориям } \\
\text { хозяйств, миллион штук }\end{array}$ & 235 & 6 & 24 & 111 \\
\hline $\begin{array}{l}\text { Поголовье крупного рогатого скота по } \\
\text { всем категориям хозяйств, тысяч голов }\end{array}$ & 514 & - & 537 & 499 \\
\hline
\end{tabular}

Источник: Народное хозяйство СССР в Великой Отечественной войне 1941-1945 гг. Статистический сборник. М.: Информационноиздательский центр, 1990. 235 с.

\section{ПРИМЕЧАНИЯ}

1.В собственноручных показаниях, данных следственным органам СССР, которые были предъявлены Нюрнбергскому трибуналу, маршал Ион Антонеску рассказал о своих встречах с Гитлером в ноябре 1940 г., в январе и мае 1941 г., на которых обсуждались вопросы, связанные с подготовкой войны против Советского Союза.

Говоря о третьей встрече с Гитлером, состоявшейся в Мюнхене, на которой присутствовал министр иностранных дел Германии Риббентроп, Антонеску заявил: «На этой встрече... мы уже окончательно договорились о совместном нападении на Советский Союз».

В тех же показаниях Антонеску поведал: «Гитлер подчеркнул, что Румыния не должна стоять вне этой войны, так как для возвращения Бессарабии и Северной Буковины она не имеет иного пути, как только воевать на стороне Германии. При этом он сказал, что за нашу помощь в войне Румыния сможет оккупировать и администрировать и другие советские территории, вплоть до Днепра» (Нюрнбергский процесс. Сборник материалов: в 8 т. М.: Юридическая литература, 1987. Т. 1. С. 589-590). 
2. Дивизия участвовала в советско-финской войне (1939-1940 гг.) в составе 9-й армии, в освобождении Бессарабии и Северной Буковины от румынских захватчиков в 1940 г.

3. Командующим войсками вновь созданного Южного фронта назначался генерал армии И.В. Тюленев, который уже 22 июня выехал в Винницу, где должно было располагаться управление фронта (Тюленев И.В. Через три войны. 2-е изд., испр. и доп. М.: Воениздат, 1972 г. С. 125).

4. Георгий Константинович Жуков в своей неопубликованной работе «Советская военная стратегия. 1941-1945 гг.» писал: «Советская военная доктрина накануне войны 1941 года исходила из того, что современную войну можно выиграть только решительными наступательными операциями сухопутных, военно-воздушных и военно-морских сил. По довоенным взглядам, стратегическая оборона рассматривалась советской военной наукой как сопутствующий и взаимодействующий фактор наступательных действий, причем на второстепенных фронтах. Стратегическая оборона одновременно на всех фронтах, как вынужденный способ ведения войны, советской наукой не мыслилась и не рассматривалась» (Горьков Ю.А. Кремль. Ставка. Генштаб. Тверь: РИФ ЛТД, 1995. С. 55).

5. В своём известном приказе по армии от 22 июня 1941 г. генерал Ион Антонеску, объявив войну священной, заявил: «Солдаты! Приказываю вам перейти Прут! Уничтожайте восточного и северного врага. Освободите от красного ига большевизма наших братьев» (Цара. Кишинев. 23 июня 1992 г. С. 6).

6. 318-я Новороссийская имени ВЦИК ордена Суворова горнострелковая дивизия была сформирована 15 июля 1942 г. на базе 78-й морской стрелковой бригады.

7. 14 мая 2014 г. городские власти Катовице в «знак благодарности» разобрали монумент советским солдатам, погибшим за освобождение Польши от немецко-фашистских оккупантов, названный Памятником Благодарности, под предлогом переноса его на новое место (Источник: Телерадиокомпания «Звезда».URL: http://tvzvezda.ru/news/vstrane_i_mire/ content/201405150213-ltcv.htm (дата обращения: 20 апреля 2015).

\section{ЛИТЕРАТУРА}

Дробязко 2004 - Дробязко С.И. Под знаменами врага. Антисоветские формирования в составе германских вооруженных сил 1941-1945. М.: Эксмо, 2004. 608 с.

История 1968 - История Молдавской ССР. Т. ІІ. От Великой Октябрьской социалистической революции до наших дней / Отв. ред. С.П. Трапезников. Кишинев: Картя молдовеняскэ, 1968.814 с.

История 2002 - История Республики Молдова. С древнейших времен до наших дней. Кишинев: Elan-Poligraf, 2002. 360 с.

История Румынии 1971 - История Румынии: 1918-1970 / Ред. кол.: Н.И.Лебедев (отв. ред.), А.А. Язькова, Е.Д. Карпещенко, И.Э. Левит, Ю.А. Писарев. М.: Наука, 1971. 742 с. 
Крылов 1984 - Крылов Н.И.Не померкнет никогда / Литературная редакция Н.Н. Ланина, 2-е изд. М.: Воениздат, 1984. 558 с.

Кустрябова 1986 - Кустрябова С.Ф. Города Бессарабии 1918-1940 гг. (Социально-экономический аспект и народонаселение). Кишинев: Штиинца, 1986. 256 c.

Левит 1981 - Левит И.Э. Участие фашистской Румынии в агрессии против СССР: истоки, планы, реализация (1.ІХ.1939-19.XI.1942). Кишинев: Штиинца, 1981. 392 с.

Молдавская ССР 1975 - Молдавская ССР в Великой Отечественной войне советского народа. 1941-1945. Сборник документов и материалов. На фронтах войны и в советском тылу. Кишинев: Штиинца, 1975. Т. І. 654 с.

Молдавская ССР 1976 - Молдавская ССР в Великой Отечественной войне советского народа. 1941-1945. Сборник документов и материалов. В тылу врага. Кишинев: Штиинца, 1976. Т. ІІ. 676 с

Назария 2005 - Назария С.М. Холокост. Страницы истории (на территории Молдавии и прилегающих областей Украины в годы фашистской оккупации. 1941-1944 гг.). Кишинев: Editorial-Poligrafică “Tipografia Centrală”, 2005. 304 с.

Репида 2008 - Репида Л.Е. Суверенная Молдова. История и современность. Кишинев: ИПФ «Центральная типография», 2008. 384 с.

Россия и СССР 2001 - Россия и СССР в войнах XX века. Потери вооруженных сил. Статистическое исследование / Под общ. ред. Г.В. Кривошеева. М.: ОЛМА-ПРЕСС, 2001.608 с.

Русский корпус 1963 - Русский корпус на Балканах во время II Великой войны 1941-1945 гг. Исторический очерк и сборник воспоминаний соратников / Под ред. Д.П. Вертепова. Нью-Йорк: Наши вести, 1963. 416 с.

Суляк 2010 - Суляк С.Г. «Мстителями возвращаемся мы на молдавскую землю» // Русин. Международный исторический журнал. 2010. № 1 (19). С. 7-18.

Тарас 2004 - Тарас,Д.А. Боевые награды союзников Германии во II Мировой войне. Минск: Харвест, 2004. 208 с.

Тюленев 1972 - Тюленев И.В. Через три войны. 2-е изд., испр. и доп. М.: Воениздат, 1972 г. 240 с.

ЦАМО 1-ЦАМО (Центральный архив Министерства обороны Российской Федерации). Ф. 228. Оп. 701.Д. 58.

ЦАМО 2 - ЦАМО. Ф. 58. Оп. 18003.Д. 745.

ЦАМО 3 - ЦАМО. Ф. 58. Оп. Н-18005.Д. 8.

ЦАМО 4 - ЦАМО. Ф. 33. Оп. 687572.Д. 2533. № записи 37505703.

Царанов 2002 - Царанов В.И. Очерки социально-экономического развития Молдовы (1940-1960 гг.). Кишинев: Elan Полиграф, 2002. 218 с.

Шорников 1994 - Шорников П.М. Цена войны: кризис системы здравоохранения и демографические потери Молдавии в период Великой Отечественной войны. Кишинев: Ассоциация мед. работников им. Н.И. Пирогова, 1994. 134 с.

Шорников 2007 - Шорников П.М. Молдавская самобытность. Тирасполь: Издательство Приднестровского университета, 2007. 400 с.

Шорников 2014 - Шорников П.М. Молдавия в годы Второй мировой войны. Кишинев: Î.S. F.E.-P. «Tipografia Centrală», 2014. 448 c. 


\section{REFERENCES}

Drobyazko, S.I. (2004) Pod znamenami vraga. Antisovetskie formirovaniya $v$ sostave germanskikh vooruzhennykh sil 1941-1945 [Under the banner of the enemy. Anti-Soviet form a part of the German Armed Forces 1941-1945]. Moscow: Eksmo [In Russian].

Trapeznikov, S.P. (ed.) (1968) Istoriya Moldavskoy SSR. T.II.Ot Velikoy Oktyabr'skoy sotsialisticheskoy revolyutsii do nashikh dney [History of the Moldavian SSR. Vol. II. From the October Revolution to the present day]. Chisinau: Kartya moldovenyaske [In Russian].

Tsaranov, V.I. (ed.) (2002) Istoriya Respubliki Moldova. S drevneyshikh vremen do nashikh dney [History of the Republic of Moldova. From ancient times to the present day.]. Chisinau: Elan-Poligraf [In Russian].

Lebedev, N.I. (ed.) (1971) Istoriya Rumynii: 1918-1970 [History of Romania: 1918-1970]. Moscow: Nauka [In Russian].

Krylov, N.I. (1984) Ne pomerknet nikogda [Never fade]. Moscow: Voenizdat [In Russian].

Kustryabova, S.F. (1986) Goroda Bessarabii 1918-1940 gg. (Sotsial'noekonomicheskiy aspekt i narodonaselenie) [The cities of Bessarabia in 1918-1940. (Socio-economic aspect and population)]. Chisinau: Shtiintsa [In Russian].

Levit, I.E. (1981) Uchastie fashistskoy Rumynii v agressii protiv SSSR: istoki, plany, realizatsiya (September 1, 1939 - November 19, 1942) [Participation of Romania in the fascist aggression against the USSR: sources, plans, implementation (1.IX.1939-19.XI.1942)]. Chisinau: Shtiintsa [In Russian].

Levit, I.E. (ed.) (1975) Moldavskaya SSR v Velikoy Otechestvennoy voyne sovetskogo naroda. 1941-1945. Sbornik dokumentov i materialov. Na frontakh voyny i v sovetskom tylu [Moldavian SSR in the Great Patriotic War of the Soviet people. 1941-1945. Collection of documents and materials. On the fronts of the war and in the Soviet rear]. Chisinau: Shtiintsa. Vol. I [In Russian].

Levit, I.E. (ed.) (1976) Moldavskaya SSR v Velikoy Otechestvennoy voyne sovetskogo naroda. 1941-1945 [In Russian].

Sbornik dokumentov i materialov. V tylu vraga [Moldavian SSR in the Great Patriotic War of the Soviet people. 1941-1945. Collection of documents and materials. Behind the Enemy Lines.]. Chisinau: Shtiintsa. Vol. II [In Russian].

Nazariya, S.M. (2005) Kholokost. Stranitsy istorii (na territorii Moldavii i prilegayushchikh oblastey Ukrainy v gody fashistskoy okkupatsii. 1941-1944 gg.) [Holocaust. Pages of History (in Moldova and adjacent regions of Ukraine during the Nazi occupation. 1941-1944.)]. Chisinau: Editorial-Poligrafică [In Russian].

Repida, L.E. (2008) Suverennaya Moldova. Istoriya i sovremennost' [The sovereign Moldova. The history and modernness]. Chisinau: Tsentral'naya tipografiya [In Russian].

Krivosheev, G.V. (ed.) (2001) Rossiya i SSSR v voynakh XX veka. Poteri vooruzhennykh sil. Statisticheskoe issledovanie [Russia and the Soviet Union in the wars of the 20th century. Military losses. A statistical research]. Moscow: OLMAPRESS [In Russian]. 
Vertepov, D.P. (ed.) (1963) Russkiy korpus na Balkanakh vo vremya II Velikoy voyny 1941-1945 gg. Istoricheskiy ocherk i sbornik vospominaniy sorat-nikov [The Russian Corps on the Balkans during the Second Great War of 1941-1945. A historical review and collection of memories]. New York: Nashi vesti [In Russian].

Sulyak, S.G. (2010) "Mstitelyami vozvrashchaemsya my na moldavskuyu zemlyu" ["We return to Moldova as avengers"]. Rusin. Mezhdunarodnyy istoricheskiy zhurnal - Rusin. International Journal of History. 1 (19) [In Russian].

Taras, D.A. (2004) Boevye nagrady soyuznikov Germanii vo I/ Mirovoy voyne [Martial award of Germany's allies in World War II]. Minsk: Kharvest [In Russian].

Tyulenev, I.V. (1972) Cherez tri voyny [After three wars]. Moscow: Voenizdat [In Russian].

The Central Archives of the Russian Ministry of Defence (TsAMO). Fund 228. List 701. File 58 [In Russian].

Tsentral'nyy arkhiv Ministerstva oborony Rossiyskoy Federatsii [The Central Archives of the Russian Ministry of Defence] (TsAMO). Fund 58. List 18003. File 745 [In Russian].

The Central Archives of the Russian Ministry of Defence (TsAMO). Fund 58. List N-18005. File 8 [In Russian].

The Central Archives of the Russian Ministry of Defence (TsAMO). Fund 33. List 687572. File 2533. No. 37505703 [In Russian].

Tsaranov, V.I. (2002) Ocherki sotsial'no-ekonomicheskogo razvitiya Moldovy (1940-1960 gg.) [Essays on the socio-economic development of Moldova (1940-1960)]. Chisinau: Elan Poligraf [In Russian].

Shornikov, P.M. (1994) Tsena voyny: Krizis sistemy zdravookhraneniya i demograficheskie poteri Moldavii v period Velikoy Otechestvennoy voyny [The price of war: Crisis of the health care system and demographic losses in Moldavia during the Great Patriotic War]. Chisinau: Association of Medical Workers [In Russian].

Shornikov, P.M. (2007) Moldavskaya samobytnost' [Moldavian identity]. Tiraspol: Transdniestria State University [In Russian].

Shornikov, P.M. (2014) Moldaviya v gody Vtoroy mirovoy voyny [Moldova during the Second World War]. Chisinau: Tipografia Centrală [In Russian].

Суляк Сергей Георгиевич - кандидат исторических наук, доцент, старший научный сотрудник лаборатории междисциплинарных исследований Национального исследовательского Томского государственного университета, главный редактор международного исторического журнала «Русин», президент Общественной ассоциации «Русь» (Республика Молдова).

Sulyak Sergey - Candidate of Historical Sciences, Associate Professor, Senior Researcher at the Laboratory for Interdisciplinary Research of National Research Tomsk State University, Editor-in-Chief of the International Historical Journal Rusin, President of the Association "Rus" (Republic of Moldova).

E-mail: sergei_suleak@rambler.ru 